\title{
Bultmann e Heidegger: entre desmitologização teológica e destruição fenomenológica.
}

Dr. Alexandre Marques Cabral

O presente artigo tem como objetivo primário assinalar em que medida pode ser afirmado que há algum tipo de relação entre o procedimento metodológico heideggeriano chamado no parágrafo 6 de Ser e tempo de destruição e o procedimento hermenêutico desmitologizador inerente à teologia existencial de Rudolf Bultmann. Aventa-se a hipótese, que deverá ser testificada ao longo da investigação, de que a desmitologização bultmanniana funciona como análogo teológico do procedimento filosófico da destruição. Para tanto, deve-se esclarecer o que Bultmann entende por desmitologização e como ela, assim como a destruição heideggeriana, possui um caráter positivo, à medida que apropria-se da tradição bíblico-teológica com a finalidade de deixar vir a lume o esteio existencial onde suas narrativas encontram seu fundamento. Deste modo, o artigo sinaliza a existência de um horizonte positivo para se compreender a mútua influência sofrida e exercida por Heidegger e pela teologia protestante existencial de Marburg, que encontra em Bultmann seu maior expoente. Consequentemente, isto parece assinalar que a obra heideggeriana, sobretudo no que concerne ao projeto de Ser e tempo, inscreve diversos elementos presentes na teologia existencial contemporânea no âmbito ontológico-existencial, o que equivale a supor que a existencialidade do ser-aí é compreendida por Heidegger à luz de elementos derivados da tradição cristã.

PALAVRAS-CHAVE desmitologização; destruição; teologia existencial 
This article aims to point out that the primary measure can be stated that there is some relationship between Heidegger's methodological procedure named in paragraph 6 of Being and Time of destruction and the procedure demythologizing hermeneutics inherent existential theology of Rudolf Bultmann. Advocate the hypothesis, that should be attested throughout the investigation, of the functions as Bultmann's demythologization functions as the analogous theological of procedure philosophical destruction. To do so, we must clarify what Bultmann means by demythologizing and how she, like Heidegger's destruction, has a positive character, as it appropriates the biblical-theological tradition in order to leave came into the mainstay existential where the narratives are based. Thus, the article indicates the existence of a positive horizon to understand the suffering and mutual influence exerted by Heidegger and the existential protestant theology in Marburg that Bultmann is in its greatest exponent. Consequently, this seems to point out that Heidegger's work, especially with regard to the project of Being and Time, sign various elements present in contemporary existential theology in scope ontological-existential, which amounts to assuming that the existentialism of being-there is understood by Heidegger in the light of elements derived from the christian tradition.

KEY-WORDS $\begin{aligned} & \text { Demythologizing, protestant theology, destruction, } \\ & \text { existential, myth. }\end{aligned}$ 
O caminho de pensamento de Martin Heidegger abarca certamente uma pluralidade de aspectos debitários de diversas relações com autores da tradição. Conhecemos, entretanto, somente alguns dos autores com os quais Heidegger se relacionou. Isto se deve, ao que parece, ao fato de que a pesquisa em torno da obra heideggeriana interessa-se, sobretudo, pelos autores que aparentemente mais interferiram no projeto de Ser e tempo ou nos aspectos implícitos ao pensamento desenvolvido após a viragem (die Kehre). É assim que ouvimos falar das relações entre Heidegger e Nietzsche, Heidegger e Husserl, Heidegger e Dilthey, Heidegger e Jünger, etc. Contudo, isto assinala somente a posição hermenêutica previamente assumida pela pesquisa sobre a obra heideggeriana ao longo dos últimos decênios.

Certamente, autores relevantes para a compreensão da obra heideggeriana são sistematicamente deixados de lado por esta mesma pesquisa. É o que acontece com a escola teológica de Marburg, por vezes mencionada por alguns comentadores da obra heideggeriana, mas pouco explicitada por eles mesmos, no que concerne aos detalhes conceituais da relação de Heidegger com a teologia protestante do século XX (Cf. GADAMER, 2002, pp, 39-52). Como a obra heideggeriana, sobretudo o projeto de Ser e tempo, se determinou por meio de contatos que o próprio Heidegger teve com a escola teológica de Marburg, quando trabalhou na Universidade de Marburg ao lado, dentre outros, de Rudolf Bultmann, o eminente biblista do século XX? Ainda que biograficamente se saiba que Heidegger teve contato tanto com a teologia católica (por exemplo, por meio do contato com as aulas de Carl Braig) quanto com a teologia protestante, ainda se deve responder como Heidegger relacionou-se com os questionamentos e com os elementos da teologia contemporânea com os quais teve contato. A compreensão da relação entre Heidegger e a teologia protestante do século XX não é destituída de dificuldades. Duas menções deixam clara tal dificuldade. Pode-se observar, inicialmente, a preleção de 1924 publicada com o título O conceito de tempo que foi pronunciada inicialmente para a Sociedade de Teólogos de Marburg. Nela, Heidegger questiona, à luz de um problema eminentemente teológico, se é possível que o tempo encontre seu sentido na eternidade e se é possível falar do tempo a partir da eternidade. O posicionamento tradicional deste problema deixa vir a lume o pressuposto de que "conhecemos a eternidade e a compreendemos suficientemente" (HEDEGGER, 1997, p, 7).

Entretanto, não podemos compreender o tempo a partir da eternidade, pelo simples fato de não podermos pular por sobre a nossa sombra, sombra esta que 
não é outra senão nossa finitude-temporalidade. A eternidade não pode ser nada senão um modo de ser temporal, que se determina em relação à temporalidade estrutural do ser-aí. Se a filosofia tem algo a dizer acerca da eternidade, deve ela ater-se à descrição da temporalidade constitutiva do ser-aí que somos. Nas palavras de Heidegger: "O filósofo não crê. Se o filósofo questiona o tempo, ele está decidido a compreender o tempo a partir do tempo relacionado ao aí, o que parece ser a eternidade, mas se mostra como mero derivado do ser temporal" (Ibidem, p, 9). Com estas palavras fica claro que Heidegger não discute a questão da relação entre tempo e eternidade a partir do horizonte da fé, mas à luz da fenomenologia, o que parece inviabilizar uma compreensão positiva da interferência da teologia de Marburg em seu pensamento inicial.

Um segundo exemplo pode ser vislumbrado no texto "Fenomenologia e Teologia”, de 1927, publicado posteriormente em Marcas do caminho. Também este texto foi apresentado para os teólogos de Marburg e deixa claro como Heidegger atribui mais originariedade à filosofia (entendida como fenomenologia) que à teologia. Nele, Heidegger relaciona-se de certo modo positivamente com a teologia cristã, mesmo que ainda preserve características metodológicas ateias, isto é, destituídas de qualquer referência a questões e princípios metafísico-teológicos. O que importa é, sobretudo, caracterizar o modo de articulação da relação positiva entre teologia e fenomenologia. Assumindo primeiramente um viés desconstrutivo, em consonância com seu projeto destrutivo já esclarecido e tematizado em Ser e tempo (Cf. HEIDEGGER, 2006, §6), Heidegger reformula a definição tradicional de teologia, que a considera "ciência de Deus" (HEIDEGGER, 2008, p, 70). Para Heidegger, a teologia não possui Deus como objeto de especulação. Por isso, "Teologia é a ciência da fé" (Ibidem, p, 65). Não se trata, porém, de posicionar a fé como objeto de tematização da teologia. A teologia é a ciência da fé, porque "é a ciência daquilo que é desvelado na fé, isto é, daquilo em que se crê" (Idem). Neste sentido, a teologia remete-se à fé porque esta, não sendo um simples consentimento a um conjunto de proposições impossíveis de serem verificadas pela razão e condicionadas pelas proposições teológico-dogmáticas, é a condição de possibilidade do dizer teológico. Isto deflagra um gesto heideggeriano presente na primeira fase de sua obra. Trata-se da tentativa de fundamentar as ciências a partir de bases fenomenológico-existenciais. À medida que a fé não é um simples consentimento ou anuência a "um emaranhado de sentenças sobre estados de fato e ocorrências" (Ibidem, p, 66), ela revela-se como um comportamento existencial do ser-aí. Sendo assim, a fé é responsável por um determinado campo de aparição dos entes. Por isso, diz Heidegger: "a fé é um modo de existência do 
ser-aí humano" (Ibidem, p, 63), ou seja, ela responde por um modo específico de abertura de mundo para o ser-aí. Em outras palavras: a fé identifica-se com um projeto compreensivo de sentido, que estrutura o modo de desvelamento do campo de aparição (mundo) de uma miríade de entes em relação aos quais o ser-aí se relaciona por meio de seus comportamentos.

Delimitando o campo de tematização da preleção à teologia cristã, Heidegger fundamenta a ciência teológica na fé. No entanto, o que ele tem em vista com o termo ciência nada mais é do que um comportamento específico do ser-aí que depende de um modo específico de compreensão que, de modo temático, descerra "um certo âmbito de abrangência" que, por sua vez, possibilita "uma objetivação e questionamento teorético" (Ibidem, p, 60), de um determinado campo fenomênico. Este âmbito descerrado é o "positum" para o comportamento científico. O descerramento referido é um tipo de compreensão de ser. No caso da teologia, ela é uma ciência positiva, que depende da fé enquanto tipo de compreensão de ser responsável pela sua positividade. Não sendo a fé um consentimento irracional a determinados estados de fato, ela é o lugar em que Cristo se mostra para o ser-aí como seu correlato intencional. Certamente influenciado pela teologia paulina e luterana, o Cristo que se dá para a fé é o Cristo crucificado. Não sendo meramente um dado historiográfico, a cruz revelada à fé só aparece para a fé por causa da fé. Justamente aí está o cerne da revelação. $\mathrm{Na}$ fé, a revelação não é o anúncio de um dado objetivo escriturístico, mas o tomar parte (participar) no "acontecimento da crucifixão" (Ibidem, p, 63). Participando do acontecimento da cruz, o ser-aí vem a ser cristão. Esta "metamorfose existencial" é definida por Heidegger como um renascimento. Por isso, a equação: " $f e ́=$ renascimento" (Ibidem, p, 64). Desta experiência existencial emerge o campo de discursividade da teologia. Seu critério de validade, portanto, não pode ser fornecido por outras ciências, mas sempre pela fé, que é a condição (existencial) transcendental da própria teologia. Somente a partir da fé a teologia tem seu sentido salvaguardado. Este não é outro senão fornecer "a clarividência do acontecer cristão, relevada na credulidade e com seus limites traçados pela própria credulidade" (Ibidem, p, 66).

A reabilitação da teologia pela experiência existencial da fé não consuma o sentido derradeiro do escrito "Fenomenologia e Teologia". Na esteira de Ser e tempo, Heidegger preocupa-se em mostrar as raízes pré-cristãs - portanto, a condição de possibilidade da própria fé - como fundamento ontológico-existencial da própria teologia. A fé seria tão-somente um modo de ser existenciário e não a estrutura mesma existencial do ser-aí. A teologia, enquanto saber ôntico, está assentada em uma verdade mais originária que a fé. Esta última congrega em si 
"o ser-aí pré-cristão" que nela está "co-implicado de maneira ontológico-existencial” (Ibidem, p, 73). Se isto é verdade, então, todos os conceitos teológicos possuem em si "um conteúdo pré-cristão" (Ibidem, p, 74). Consequentemente, os modos de ser (existenciais) que caracterizam ontologicamente o ser-aí fundamentam a própria teologia. Sabendo que a filosofia, enquanto fenomenologia hermenêutica, é o conhecimento que descreve as estruturas do ser-aí, pode-se afirmar que a própria filosofia torna-se essencial para a teologia. Ela lhe serve como saber corretivo. Os conceitos teológicos podem ganhar clareza com a sua remissão à estrutura existencial do ser-aí. O caráter corretivo da filosofia em relação à teologia não a reduz a ser serva desta ciência. A filosofia não é ancillae theologiae, como reza a conhecida expressão medieval. Antes disto, ela sobrevive em sua tarefa mesmo sem qualquer referência à teologia. Com isto, Heidegger não funcionaliza a filosofia, mas lhe garante autonomia e maior originariedade que a ciência teológica.

Essas informações já nos permitem vislumbrar a problemática relação entre Heidegger e a teologia de Marburg. Se há uma relação entre os pensamentos de ambos, certamente o ponto de interseção não pode ser encontrado com facilidade. Heidegger, até onde sabemos, não afirma explicitamente nenhuma vez que seu pensamento é debitário da crítica teológica da escola teológica de Marburg. Entretanto, ainda assim é necessário que se investigue a relação de Heidegger com esta escola teológica. Para tanto, o presente artigo propõe-se a assinalar a possível correlação entre o procedimento desmitologizador de Rudolf Bultmann e o procedimento destruidor da fenomenologia hermenêutica de Heidegger. Esta escolha não é aleatória. Bultmann é, certamente, o teólogo mais expressivo da escola protestante de Marburg e, ele mesmo, esteve pessoalmente ao lado de Heidegger, em contato com o projeto de Ser e tempo e ministrando cursos com ele, sobretudo entre 1923 e 1928 (Cf. ALTMANN, 2001). Por outro lado, é evidente nas obras de Bultmann a utilização de elementos da analítica existencial heideggeriana. Apesar disto, deve-se ressaltar que o próprio Bultmann coloca ressalvas em sua apropriação do pensamento heideggeriano em meio ao seu projeto de uma teologia existencial. No conhecido ensaio de 1941, "Novo Testamento e mitologia", Bultmann afirma que "a análise existencialista do ser-aí em Martin Heidegger parece ser apenas uma exposição filosófica profana da visão neo-testamentária do ser-aí humano" (BULTMANN, 1999, p, 28). Isto parece assinalar que Bultmann enxerga Heidegger à luz de uma compreensão prévia do modo de determinação neotestamentário do ser-aí humano. Ainda que não saibamos muito bem como Heidegger foi influenciado pela teologia de Marburg e até que ponto esta teologia, sobretudo na obra de Bult- 
mann, é efetivamente debitária de Heidegger, pode-se pensar a relação entre desmitologização e destruição como um ponto de contato entre ambos os pensamentos e como paradigma para se pensar até que ponto pode-se vislumbrar certa interferência entre filosofia existencial heideggeriana e teologia existencial protestante. O presente artigo possui como proposta principal desenvolver a hipótese de que há uma relação entre os dois procedimentos metodológicos assinalados (desmitologização e destruição) e que tal relação deixa vir a lume o modo como a destruição fenomenológica funciona analogicamente em outro campo compreensivo que não o da filosofia. Para tanto, iremos nos ater aos textos bultmannianos onde tal procedimento é descrito e onde sua relação com Heidegger aparece com clareza. A partir disto, tentaremos mostrar como a desmitologização deixa repercutir, no âmbito teológico, os intentos primordiais da destruição heideggeriana. Com isso, não mostraremos, certamente, como a teologia de Marburg está presente no projeto de Ser e tempo, porém, abriremos um campo positivo para um diálogo profícuo entre Heidegger e a teologia existencial contemporânea, diálogo este do qual o próprio Heidegger não se furtou.

\section{$-2-$}

Nascido na Alemanha (Wiefelstede) aos 20 de agosto de 1884, Rudolf Karl Bultmann tornou-se um dos maiores expoentes do pensamento teológico contemporâneo. Ainda quando lecionava disciplinas em torno do estudo do Novo Testamento e também da História da Igreja primitiva, Bultmann tornara-se referência a todo estudante de teologia, seja católico ou protestante. Em Marburg, à luz de muitos elementos da fenomenologia hermenêutica heideggeriana, Bultmann construiu, sobretudo após o ensaio "Novo testamento e mitologia", de 1941, o famoso projeto teológico da desmitologização (Entmythologisierung) ${ }^{1}$, que tornou-se um marco nos estudos bíblicos contemporâneos. A complexidade deste procedimento metodológico e o alcance que ele possui na obra de Bultmann e na teologia contemporânea não nos permitem aqui obviamente empreender uma abordagem exaustiva do seu pensamento. Seu pensamento tem esteios diversificados e, especialmente no que concerne às suas bases filosófi-

1 Traduziremos aqui, diferentemente da tradução brasileira, Entmythologisierung por desmitologização e não demitologização. Deve-se também observar que, apesar de o ensaio "Novo testamento e mitologia" deixar explícito o próposito do projeto desmitologizador, já na década de 1920 tal projeto já havia sido operacionalizado, como se pode perceber na obra Jesus. Cf. BULTMANN, 2005. 
cas, possui grande densidade, o que exigiria um espaço maior que o que deve ser empreendido em um simples artigo para abarcá-lo em sua inteireza. Aqui, interessa-nos algumas considerações que assinalem a pertinência da nossa proposta. No que diz respeito ao pensamento de Bultmann, devemos inicialmente perguntar: o que ele entende por desmitologização? O que estão em jogo com este conceito? Qual o problema dos mitos para a teologia de Bultmann? Como prescindir do mito no labor teológico? É isto possível?

A palavra desmitologização já assinala uma negatividade congênita. Nela parece estar em jogo a aniquilação do poder prescritivo dos mitos e um modo de apologia de algum tipo de racionalismo. É isso que diz o prefixo português de matriz latina "des", assim como o alemão "Ent". Ambos assinalam a perversão do termo em questão ou a distorção de sua essência. Se mitologia, neste caso, parece indicar o ato de engendrar normativamente mitos, então, desmitologizar seria distorcer o poder de determinação dos mesmos mitos. Justamente isto parece ser o primeiro sentido desta expressão em Bultmann. Isto porque a desmitologização parte do pressuposto de que o homem atual, para o qual deve ser atualizada e anunciada a mensagem (Kérigma) cristã, já está inserido em um contexto histórico determinado, sobretudo pela ciência. Consequentemente, para este homem, o aparato mitológico que norteia a mensagem bíblica não mais lhe fala essencialmente. Antes disso, o poder objetivador da ciência alija de si as crenças inerentes ao universo mítico em geral. Por isso, para que a mensagem bíblica possua algum significado real para o homem do mundo tecno-científico, é mister a execução do procedimento desmitologizador. A negatividade congênita da desmitologização possui, portanto este primeiro sentido eminentemente positivo. Ela deve de certo modo desobstruir a mensagem (Kérigma) bíblica dos arcabouços mitológicos que fornecem a roupagem de suas narrativas, para que desvele o cerne da mensagem que pode ser transposta para o universo significativo do homem moderno. Uma passagem do texto " $\mathrm{O}$ problema da desmitologização" deixa claro estes elementos:

Sob desmitologização entendo um procedimento hermenêutico que interroga enunciados ou textos mitológicos quanto a seu teor de realidade.

Ao fazer isso se pressupõe que o mito fala de uma realidade, porém de uma maneira não adequada.

Ora, o termo realidade pode ser entendido num duplo sentido. Usualmente entende-se sob 'realidade' a realidade do mundo representada na visão objetivadora, a re- 
alidade dentro da qual se encontra o ser humano, na qual ele se orienta ao confrontar-se com ela, com cujo nexo ele conta e calcula a fim de dominá-la e, assim, assegurar sua vida. Essa maneira de olhar a realidade foi formada na ciência natural e na técnica por ela possibilitada.

Essa maneira de ver a realidade é, como tal, desmitologizadora, na medida em que elimina a atuação de poderes sobrenaturais acerca dos quais fala o mito - seja a atuação de poderes que colocam em andamento e mantêm o processo da natureza, seja a atuação de poderes que interrompem esse processo. (BULTMANN, 1999, p, 95)

Por desmitologização, Bultmann entende um "procedimento hermenêutico". Com isso, ele faz da desmitologização um medium interpretativo da mensagem bíblica, sobretudo neo-testamentária. O que importa a Bultmann é o "teor da realidade" dos mitos. Neste sentido, o critério de avaliação do mito provém da ideia objetiva de realidade, paradigmaticamente expressa na modernidade, nas práticas tecno-científicas. O que está em jogo nesta pressuposição é a conhecida dicotomia sujeito-objeto, que transforma a certeza e o autoasseguramento em critérios de avaliação do discurso. Ainda que Bultmann não mencione explicitamente, o pressuposto da ideia de realidade objetiva por ele pensada é o sujeito posicionador dos entes, que necessita de um movimento reflexivo prévio, para determinar-se como lugar de aparição dos entes. O que aí se manifesta é considerado objeto. Caso a objetividade seja o critério de avaliação da linguagem mítica, "o mito fala de uma realidade, porém de uma maneira não adequada". A não adequação do mito, portanto, refere-se à sua incapacidade de posicionar objetivamente o mundo. Ao mesmo tempo, Bultmann compreende a realidade como aquilo no qual o ser humano sempre se encontra e é passível de cálculo e dominação. Deste encurtamento do conceito de realidade advém o horizonte de compreensão científico. Ora, neste caso, a desmitologização é uma exigência do homem moderno. Na passagem acima, Bultmann diz que a "maneira moderna de ver a realidade é, como tal, desmitologizadora", o que indica que o seu procedimento hermenêutico já é uma tradução teológica de uma exigência que se poderia chamar de epocal, pois é a própria modernidade que é desmitologizadora por excelência. Isto porque a modernidade, por meio dos avanços tecno-científicos, obstaculizou a possibilidade de se compreender o mundo por intermédio de forças consideradas sobrenaturais, que interromperiam o curso "natural" dos entes e funcionaria como sinal da intervenção de en- 
tidades divinas no curso do mundo. Poder-se-ia conceber, então, a repercussão epocal do procedimento hermenêutico da desmitologização como sintoma de certa pragmática teológica ou de certa funcionalização teológica. Isto porque a desmitologização atenderia somente a uma demanda moderna, sem questionar o pressuposto ontológico que anima a modernidade, baseado em uma redução do real à objetividade do sujeito posicionador dos entes. Porém, não é isto que caracteriza a desmitologização. Ela busca, sobretudo, uma linha de fuga da objetivação moderna do mundo, a partir de pressupostos filosóficos advindos do aprofundamento da própria modernidade. Antes de perguntar acerca destes pressupostos, é necessário inquirir: como Bultmann compreende o mito? Quais são suas principais características? Apesar de Bultmann não elaborar uma resposta inequívoca para estas questões, algumas passagens do famoso ensaio "Novo Testamento e mitologia" e de "Jesus Cristo e mitologia" já nos possibilitam vislumbrar alguns dos elementos que ele considera essenciais:

O mito fala do poder ou dos poderes que o ser humano supõe experimentar como fundamento e limite de seu mundo, bem como de seu próprio agir e sofrer. No entanto, fala desses poderes de tal modo que conceptualmente os inclui no círculo do mundo conhecido de suas coisas e forças, e no círculo da vida humana, de seus afetos, motivos e possibilidades. (...)

Encontra expressão no mito a crença de que o mundo conhecido e disponível, em que vive o ser humano, não possui em si mesmo fundamento e alvo, mas que, contrariamente, seu fundamento e seu limite residem fora da esfera do conhecimento e do disponível. Ademais, expressa-se nele a crença de que tudo quanto é conhecido e disponível é permanentemente permeado e ameaçado pelos sinistros poderes que lhes são fundamento e limite. Finalmente, junto com os dois aspectos expostos, o mito dá expressão ao conhecimento de que o ser humano não é o senhor de si mesmo, de que é dependente não apenas dentro do mundo conhecido, mas dependente sobretudo daqueles poderes atuantes além da esfera do conhecido, e de que se pode tornar livre dos poderes conhecidos precisamente nessa dependência" (Ibidem, pp, 14-15). 
Os mitos falam dos deuses e dos demônios como de poderes dos quais o ser humano se sabe em dependência, de cujo favor necessita e cuja ira teme. Os mitos expressam a percepção de que o ser humano não é senhor do mundo nem de sua própria vida, de que o mundo no qual vive está cheio de enigmas e mistérios, e, ademais, de que também a vida humana está prenhe de mistérios e enigmas.

A mitologia expressa uma determinada compreensão da existência humana. Crê que o mundo e a vida humana têm seu fundamento e seus limites em um poder que se encontra fora de tudo aquilo que podemos calcular e controlar. A mitologia fala desse poder de forma inadequada e insuficiente, porque fala dele como de um poder mundano (Ibidem, pp, 53-54).

As passagens acima apresentam os principais elementos da compreensão bultmanniana de mito. Trata-se de uma compreensão reducionista, pois o que lhe interessa, sobretudo, é caracterizar o mito como experiência antropomórfica de mundo, na esteira de muitas considerações novecentistas acerca do mito. Tal abordagem já assinala que Bultmann considera o mito à luz da compreensão moderna de mundo, caracterizada por ele como lugar de objetivação do real. Se Bultmann leva adiante este tipo de compreensão do mito, então, para ele, todo mito passará a falar de jogos de forças sobrenaturais que determinam tanto o homem quanto o mundo, porém suas imagens são inadequadas, por terem sido retiradas de contextos intramundanos. Em outras palavras: para Bultmann, todo mito incorre no equívoco de caracterizar o supramundano por meio de discursos intramundanos, o que significa que o mito inscreve a lógica do sagrado no horizonte compreensivo dos entes intramundanos. Entretanto, Bultmann considera que nos mitos subfala a precariedade da condição humana, suscetível a poderes não domináveis e controláveis pela razão e pela vontade. Ao mesmo tempo, os mitos assinalam o caráter enigmático do mundo, o que é signo do assombro humano pelo mistério eterno do real. Duas inadequações então aparecem nos mitos: a) todo mito não se adequa à visão objetivista moderna; b) a linguagem mítica não se adequa àquilo de que quer falar, pois, como já afirmado, "os mitos atribuem uma objetividade mundana àquilo que é não-mundano"(Ibidem, p, 54). Neste sentido, para Bultmann, o mito é um tipo de linguagem e conhecimento antropocósmico que se utiliza de imagens ou signos linguísticos mundanos para expressar o não-mundano de modo não objetivo. Apesar de Bultmann não falar explicitamente de antropomorfismo, este se torna 
patente à medida que tal conceito não se manifesta somente nas projeções de características humanas em deuses ou entidades sobrenaturais, mas, sobretudo porque, para a ideia de causalidade que determina a ciência moderna, o antropomorfismo se manifesta quando nosso conhecimento não apresenta desinteresse e objetividade, mas é signo de carências ou necessidades subjetivas, mesmo que estes conhecimentos falem do mundo enquanto tal ou de deuses. Isto porque a "crença" moderna vê o mundo como o influxo de forças previamente determináveis que seguem um curso causalmente previsível, através do modo como atuam nos corpos em geral. Assim, o curso das forças e dos corpos independem do homem para se determinar. Neste sentido, o saber científico parece, na modernidade, sobretudo no mecanicismo, investigar desinteressadamente a natureza. À medida que os mitos, segundo Bultmann, tematizam poderes não controláveis pelo homem, seres sobrenaturais e deuses, eles são destituídos de objetividade, o que engendra um discurso antropomórfico.

O famoso artigo de 1941 já citado, "Novo Testamento e mitologia", caracterizou de forma nitidamente caricatural as concepções mitológicas do Novo Testamento. "O universo é considerado como dividido em três andares. No meio se encontra a terra, sobre ela o céu, abaixo dela o mundo inferior" (Ibidem, p, 5). No céu, o próprio Deus habita. Ele é distante como o é sua transcendência. Inalcançável para os homens, é fonte de aspiração e de temor. Como pólo antitético, encontra-se o inferno. Situa-se abaixo dos pés humanos e sempre estremece sua segurança, pois sinaliza o lugar da condenação humana. Nele, dor e desespero se eternizam e o homem agoniza por todo sempre. Entre céu e inferno está a Terra. Como dito no primeiro tópico desta introdução, a Terra é por antonomásia ambígua. Nela, poderes celestes e infernais se entrecruzam, interferindo nas múltiplas atividades humanas. Milagres e maldições são experiências comuns no cenário da Terra. O próprio homem torna-se suscetível de ser tomado pelas forças divinas e/ou diabólicas.

$\mathrm{Na}$ arena da Terra, o Novo Testamento encontrou a condição de possibilidade de outra imagem mítica, qual seja, a salvação antropocósmica. Nesta imagem, o tempo final acontece quando Deus envia seu filho. "Este, um ser divino preexistente, aparece na terra como um ser humano; sua morte na cruz, a qual ele sofre como um pecador, propicia expiação pelos pecados dos seres humanos. Sua ressurreição é o começo da catástrofe cósmica através da qual será aniquilada a morte, trazida ao mundo por Adão; os poderes demoníacos universais perderam seu poder" (Ibidem, p, 6). Quem seguir os rumos da Igreja, for batizado, participar dos elementos eucarísticos, comportar-se moralmente bem e crer no evangelho, participará da glória da ressurreição de Cristo e 
será salvo. Justamente isto sinaliza, para Bultmann, não somente a influência da apocalíptica judaica e do mito gnóstico da redenção em relação ao universo mitológico neotestamentário, mas sobretudo "a concepção do universo de uma época passada, ainda não moldada pelo pensamento científico" (Ibidem, p, 7). O caráter pré-científico do horizonte mítico presente no Novo Testamento inviabiliza preservá-lo atualmente. Se a ciência moderna assenta-se na objetivação dos entes, então, o caráter não objetivador dos mitos torna-se-lhe inacessível ou incompreensível. A solução para a lida com o Novo Testamento está na desmitologização. É esta que possibilita atualizar a mensagem de Novo Testamento sem preservar a ingenuidade do pensamento mítico. Mas, como acontece esta desmitologização?

Segundo Bultmann, o sentido da desmitologização já se dá no próprio Novo Testamento. A pregação escatológica de Jesus, que não se referia a qualquer tipo de futurismo, foi conservada em linguagem mítica pela comunidade primitiva. "Muito logo, porém, começou o processo de desmitologização, parcialmente com Paulo e radicalmente com João" (Ibidem, p, 62). Apesar de Paulo pensar em termos míticos a redenção cósmica, através da ressurreição de Cristo, ele transfere o problema da parousía (vinda de Cristo) para o aqui e agora (hic et nunc) da fé do cristão, o que equivale a dizer que o futurismo mitológico foi antecipado para a vida atual daquele que crê. Mas, para João, a desmitologização é ainda mais radical. Para ele, a vida eterna se dá agora. Basta crer. Bultmann chega a citar Jo 3, 36: "Quem crê no Filho tem a vida eterna; o que, todavia, se mantém rebelde contra o Filho não verá a vida, mas sobre ela permanece a ira de Deus". Paulo e João efetivam no próprio Novo Testamento procedimentos desmitologizantes. Isto já justifica sobremaneira o intuito de Bultmann, pois assinala a existência de diversas contradições neotestamentárias, que engendram, nos próprios hagiográficos (escritores sagrados), a necessidade de desmitologização.

A desmitologização de Bultmann não tem como sentido retirar a presença do mito das narrativas neotestamentárias ou da vida da fé. Antes, ela "pretende expressar a verdadeira intenção do mito, a saber, a intenção de falar acerca da verdadeira realidade do ser humano" (Ibidem, p, 101). O que está em questão para Bultmann é a relação do conteúdo mitológico com a "realidade do ser humano". Em outras palavras: "Em nosso contexto está em pauta o mito na medida em que nele se expressa uma determinada compreensão da existência humana" (Ibidem, p, 100). É a existência humana o eixo em torno do qual gira a desmitologização. Sua estrutura fundamenta os mitos ao mesmo tempo que sofre sua interferência. O problema é que há uma tendência do mito a tornar-se uma narrativa objetivadora, mesmo que não seja científica. Com isso, sua reper- 
cussão na existência humana não favorece a gênese de um modo de ser destituído de obstruções e obstáculos à sua plena realização. Porquanto a existência aparece como base estruturadora do discurso mitológico, a desmitologização assumirá alguns elementos do pensamento existencial de matriz heideggeriana como sua fonte inspiradora e propulsora. No artigo "Jesus Cristo e mitologia", Bultmann esclarece os porquês da sua escolha pelo pensamento existencial de Heidegger como móvel da desmitologização. Interessa-nos aqui destacar o fato de que a leitura da palavra bíblica possui por si só caráter existencial, à medida que a bíblia não é um livro de conteúdos teóricos, mas sobretudo um livro que se dirige à singularidade da existência de cada leitor, exigindo decisões que determinem suas conformações existenciais. A existência do leitor não está fora e isenta daquilo que é lido. Antes disto, a leitura da bíblia é uma oportunidade de transformação da existência do leitor. Isto deixa vir à baila a experiência existencial subjacente à fé cristã, sobretudo na compreensão do Kérigma. Ora, se o livro sagrado da fé cristã exige compromisso existencial, então, o pensamento existencial aparece como paradigmático para compreendê-lo. O pensamento de Heidegger, sobretudo o de Ser e tempo, torna-se imprescindível porque fornece elementos teóricos que desobjetivam o pensamento moderno e permitem assinalar a dinâmica existencial pertencente à vida da fé e ao livro cristão que sustenta a própria fé (Cf. Ibidem, pp, 69-78).

\section{$-3-$}

"Agora, pois, a tarefa é a de interpretar existencialisticamente também a mitologia dualista do Novo Testamento" (Ibidem, p, 20). A interpretação existencial que norteia o procedimento desmitologizador realiza uma "destruição crítica da mitologia neotestamentária" (Ibidem, p, 13). A desmitologização é, portanto, um tipo de destruição. O que se entende por destruição desmitológica parece ser o eco da ideia heideggeriana de destruição presente sobretudo no parágrafo 6 de Ser e tempo. Porquanto esta ideia conecta a desmitologização de Bultmann com o problema da existência humana, devemos brevemente nos deter na elucidação do modo como o sentido da destruição heideggeriana de certo modo reaparece na teologia de Bultmann, o que exige o esclarecimento prévio do que Heidegger entende por destruição. No que concerne a esta tarefa, o referido parágrafo de Ser e tempo serve-nos de fio condutor. Nele, o que está em jogo, como deixa claro seu título, é a destruição da história da ontologia. A ontologia torna-se em Heidegger uma questão dotada de "historicidade", à 
medida que a questão do ser, que caracteriza o problema ontológico por antonomásia, refere-se antes de tudo a mundos históricos específicos, que condicionam e possibilitam diversos campos ou regiões dos entes a serem estudados por diversas ciências ou saberes (Cf. CASANOVA, 2009). Destas regiões, as ciências retiram seus "conceitos fundamentais" que guiam todas as pesquisas positivas relacionadas àquela determinada região de entes (Cf. HEIDEGGER, 2006, §3). Cada ciência depende de um modo histórico de abertura da totalidade do ente. Desta totalidade, os saberes regionais, como as ciências, retiram a medida única para efetuar um recorte que determine um campo específico de entes a serem tematizados. À medida que Heidegger assume o caráter histórico das ontologias, seu problema será o de elucidar o modo como elas se articulam. A tal questionamento Heidegger denominou de "ontologia fundamental" (HEIDEGGER, 2009, §4), pois esta tematiza justamente o lugar de articulação das ontologias em geral. Este lugar é a existência humana, que Heidegger nomeia de Dasein ou ser-aí, pois tal termo, que em alemão indica o simples fato de algo existir, é composto pela adjunção de um advérbio de lugar $(D a)$ e o verbo ser (Sein) (Cf. CASANOVA, 2006). Isto indica que a abordagem heideggeriana irá se ater a uma dimensão do homem em que ele aparece como o lugar de determinação do ser, que aqui se confunde com os mundos históricos que determinam o próprio caráter histórico das ontologias. A tarefa da ontologia fundamental passa a exigir a destruição da história da ontologia, pois a questão ou pergunta pelo ser (Seinsfrage) "descalcifica" a ideia tradicional de ser que se identifica com a simples presentidade do ente, ou seja, com a propriedade do ente que fundamenta sua presença dada ou objetiva. À medida que esta compreensão do ser, que fundamenta a metafísica da presença, passa a determinar as múltiplas ontologias históricas do Ocidente, ao ponto de gerar o obscurecimento do próprio problema do ser, o empreendimento da retematização do sentido do ser exige a destruição da história da ontologia.

Se o ser-aí é o índice de articulação das ontologias históricas, então, ele mesmo relaciona-se com o ser historicamente. Como a história da ontologia está marcadamente estruturada pela metafísica da presença; como esta metafísica é um obstáculo para a retomada do problema do sentido do ser e como o ser-aí determina-se pela sua relação com as ontologias históricas, então, para que se assuma o problema do ser, é necessário desobstruir estas ontologias históricas para esclarecer suas bases e sua relação com o sentido do ser. Esta é a tarefa da destruição fenomenológica heideggeriana. Ela pergunta pela proveniência dos conceitos ontológicos basilares da tradição, delimitando suas raízes e seu poder de nomeação dos fenômenos. O esteio dos conceitos da tradição é o mundo 
histórico que os fundamenta. $\mathrm{O}$ modo de determinação deste mundo passa a fornecer a medida para se esclarecer como o ente foi compreendido de tal ou qual modo. Como o ser-aí está na base das determinações ontológicas e como ele desdobra seu ser sempre existencialmente, os conceitos decisivos da tradição têm bases existenciais que os fundamentam. Na destruição, portanto, há o abalamento "de uma tradição petrificada" para que "se renovem os entulhos acumulados" (Ibidem, §6). Assim, o ser-aí não se torna escravo das cristalizações históricas da ontologia e recupera as bases existenciais dos fenômenos. Destarte, a destruição não possui tarefa negativa. Não é aniquilação da história da ontologia, mas a busca pelas raízes dos próprios conceitos da tradição e a liberação do campo existencial onde as ontologias se fundam. Nas palavras de Heidegger:

Essa comprovação da proveniência dos conceitos ontológicos fundamentais mediante uma exposição investigadora de suas respectivas 'certidões de nascimento' nada tem a ver com uma relativização das perspectivas ontológicas. A destruição também não tem o sentido negativo de arrasar a tradição ontológica. Ao contrário, ela deve definir e circunscrever a tradição em suas possibilidades positivas, e isso quer sempre dizer em seus limites, tais como de fato se dão na colocação do questionamento e na delimitação, assim pressignada, do campo de investigação possível. Negativamente, a destruição não se refere ao passado; a sua crítica volta-se para o 'hoje' e para os modos vigentes de se tratar a história da cultura ou pela história dos problemas. Em todo caso, a destruição propõe-se a sepultar o passado em nada negativo, tendo uma intenção positiva. Sua função negativa é implícita e indireta (Idem).

$\mathrm{Na}$ destruição heideggeriana, os fenômenos em geral aparecem a partir de bases existenciais. Por isso, a questão da existência ganha relevância em sua obra de 1927 (Ser e tempo). Por existência, Heidegger não compreende a simples ocorrência ou subsistência de algo. A existência deflagra a essência mesma do ser-aí (Cf. Ibidem, §9). Em um primeiro momento, Heidegger diz que, por ser existência, o ser-aí não possui "propriedades simplesmente dadas" (Idem), pois ele é marcado por uma indeterminação ontológica congênita, que caracteriza a negatividade de seu ser. Neste sentido, a existência relaciona-se com 
a ideia de poder-ser (Sein-können), como fica claro no parágrafo 31 de Ser e tempo. Ser poder-ser é não ser a priori nada; é não ter propriedades que previamente determinem o ser-aí, como faculdades intelectivas, pulsionais, emotivas, sexuais, sociais, etc. Por isso, o ser-aí sempre é alguém, devido à assunção e desdobramento de determinadas possibilidades de ser. Isto mostra que o poder-ser existencial do ser-aí não se preserva "imaculado", pois isso seria uma contradição, uma vez que ser um puro poder-ser é algo já determinado, o que contradiz a ideia de poder-ser como indeterminação ontológica do ser-aí. Assim, o poder-ser já aparece em um campo delimitador de possibilidades de ser. Neste sentido, existência é ek-sistência, ou seja, ser-fora-de-si, em meio a um horizonte delimitador do campo de desdobramento do poder-ser do ser-aí. Este campo é chamado de mundo, cujos contornos não serão tematizados aqui. Sendo "poder-ser-no-mundo" (Ibidem, §31), o ser-aí assume conformações de si, à medida que assume determinadas possibilidades de ser. Em meio a tais possibilidades, tanto seu ser quanto o ser dos entes em geral são decididos em suas respectivas conformações ontológicas. Ora, isto faz com que o problema da ontologia fundamental (elucidação do sentido do ser) seja remetido à existência do ser-aí, enquanto lugar de manifestação dos múltiplos sentidos históricos do ser (mundos). Pode-se, a partir destas considerações, perguntar: qual a interconexão há entre o projeto destruidor da fenomenologia heideggeriana e a desmitologização bultmanniana?

\section{$-4-$}

A destruição desmitologizante de Bultmann, à medida que busca explicitar o sentido existencial dos mitos, trabalha com a ideia de positividade pertencente à destruição heideggeriana. Os mitos não são aniquilados na desmitologização, mas são perfurados, para que deixem à mostra o lastro existencial que sustenta sua narrativa. Se Bultmann enxerga nos mitos um tipo de cosmovisão passada, então, a medida ontológica de nosso tempo (tecno-ciência) não nos permite levar em consideração a cosmovisão mítica antiga. No entanto, o solo que fundamenta tanto a ciência quanto os mitos é a existência. Por isso, pode-se dialogar com o significado existencial dos mitos, mesmo na era tecno-científica. Isto esclarece as considerações anteriores sobre a incompatibilidade entre mito e ciência. Não se trata de uma opção de Bultmann em favor da ciência moderna. Antes, trata-se de mencionar os choques das cosmovisões, como estratégia para deslocar o problema da leitura bíblica para um plano ontológico mais radical ou 
originário que o plano das cosmovisões, a saber, o plano existencial. Neste plano, está em jogo para Bultmann duas possibilidades de realização existencial do homem: a autenticidade e inautenticidade. Estas são modos de ser analisados por Heidegger em Ser e tempo. Para Heidegger, não se trata de escolher um dos dois, como se tal caracterização possibilitasse criar algum tipo de normatividade moral. Antes, trata-se de descrever modos possíveis de desdobramento existencial do ser-aí. A importância desta descrição, em Heidegger, está em mostrar a perpetuação ou ruptura histórica das ontologias em geral. Pois, é somente através da singularização do ser-aí, lugar de aparição da autenticidade (Eigentlichkeit), que os mundos históricos (ontologias) podem se diferenciar (Cf. CASANOVA, 2009). Ao mesmo tempo, a questão da inautenticidade ou impropriedade explica o lugar de gênese das ontologias marcadas pela metafísica e pelas concomitantes objetivações teóricas dos entes. Na inautenticidade, não somente o ser-aí desonera-se da responsabilidade de assumir a problematicidade do seu poder-ser, como os discursos teóricos têm sua condição de possibilidade assegurada, pois estes surgem da ideia de que os entes são dotados de propriedades e tal ideia só é possível no horizonte da decadência (Verfalenheit) do ser-aí no mundo fático que é o seu.

A partir do binômio autenticidade/inautenticidade, Bultmann explica o conteúdo existencial originário dos mitos, ao mesmo tempo que este binômio norteia a própria destruição desmitologizadora. Bultmann não diz que toda mitologia neotestamentária relaciona-se com o modo de ser da autenticidade. Ele diz sobretudo que a experiência da palavra de Deus, que surge da escuta do anúncio (Kérigma) bíblico, deve relacionar-se com a autenticidade, sendo esta o tipo de existência que não se orienta pela segurança do mundo impróprio, onde tudo é disponível. Ou seja, o caráter crítico, dramático e inseguro da existência é assumido na autenticidade. Ora, como a fé é um modo de configuração existencial do ser-aí e como ela articula a existência de modo próprio ou autêntico, a palavra de Deus relaciona-se com o si próprio (Selbstsein) do homem. Já em 1925, Bultmann afirmou: "quando se pretende falar de Deus, é preciso, ao que tudo indica, falar de si próprio" (BULTMANN, 2001, p, 23). Se Deus não é um objeto disponível no mundo, então, não é a existência inautêntica o lugar paradigmático para se falar de sua experiência, pois é somente nela que os entes em geral, inclusive Deus, podem aparecer como objeto. A existência própria será este lugar. Ela tanto se determina explicitamente na fé, quanto determina o discurso sobre Deus. Consequentemente, Bultmann fará da autenticidade existencial critério para desconstruir as mitologias neotestamentárias e haurir delas seus diversos significados para fé, concomitantemente, para a existência 
em geral. Tais considerações aparecem nitidamente na tematização bultmanniana da mensagem de Jesus nos evangelhos sinóticos. Nela, Bultmann mostra que a mensagem do reinado de Deus (Bultmann não fala de "reino", mas de reinado de Deus), que norteia a vida de Jesus, exige a cada vez, aqui e agora, uma decisão por parte do homem, que deve traduzir a vontade de Deus em sua situação existencial concreta. Assim, o ser humano rompe a lógica do pecado, onde tudo aparece como disponível e dotado de identidades ontológicas fixas, engendrando um novo futuro, onde nada é disponível. Nesta situação existencial, o homem assume seu ser mais próprio, que não se identifica com qualquer noção metafísica de natureza humana (Cf. BULTMANN, 2005).

Bultmann não fará qualquer esclarecimento cabal da existência humana, apesar de levar adiante as considerações heideggerianas em Ser e tempo, como fica claro no artigo citado "O problema da desmitologização". Neste sentido, o problema da temporalidade que se manifesta na existência autêntica e que Heidegger, em Ser e tempo, mostra ser o sentido do ser-aí (Cf. HEIDEGGER, $2009, \S 65)$, torna-se critério de esclarecimento da existência do homem de fé. Por isso, a questão da escatologia ganhará profunda relevância em Bultmann. ${ }^{2}$ Antes de aparentemente ser a fala de um evento antropocósmico futuro, o evento escatológico torna-se antecipado pela fé e confere à existência um sentido autêntico de autorrealização. Tal compreensão só é possível, se a existência autêntica apresenta-se em sua temporalidade antecipadora do futuro. A escatologia existencial torna-se emblemática, porquanto deixa viger um tipo de existência onde a fé se conjuga com a autenticidade, sem que com isto a existência suprima sua dramaticidade. Destarte, a mitologia bíblica encontra aqui o seu eixo hermenêutico e a vida cristã descobre um critério não mais objetivo, tampouco mítico, para se desenvolver. Por isso, Bultmann desconstrói as pretensões dos métodos histórico-críticos e da teologia liberal do século XIX. Tais pretensões ainda possuem resquícios de práticas objetivantes, o que assinala as bases existenciais inautênticas que as fundamentam. Isto porque eles almejam a segurança de um discurso que positiva a mensagem cristã, negando por sua vez o caráter performático, singular e problemático da existência humana. Isto serve de indicativo de que tais propostas teológicas fogem da fé, já que esta é um modo de ser que consente com o modo autêntico de realização da existência humana (Cf. RIDDERBOS, 1966).

2 Deve-se observar que no curso "Introdução à fenomenologia da religião", que Heidegger ministrou entre 1920 e 1921, suas interpretações do epistolário paulino, sobretudo das cartas aos Galátas e I e II carta aos Tessalonicenses, Heidegger, assim como Bultmann, posiciona a escatologia cristã como eixo em torno do qual se estruturou a experiância cristã da vida fática do cristianismo primitivo. Cf HEIDEGGER, 2010. 
Ainda que haja uma gama de elementos importantes no projeto desmitologizador de Bultmann, as informações precedentes já nos ajudam a efetivar algumas ponderações, a partir do objetivo anteriormente mencionado. A relação entre desmitologização e destruição fenomenológica apareceu claramente por meio das informações precedentes. Tanto Heidegger quanto Bultmann desconstroem discursos sedimentados da tradição com a finalidade de explicitar suas bases existenciais e despertar sua vitalidade. Enquanto Heidegger procede destrutivamente (ou desconstrutivamente) com a tradição filosófica e empreende uma efetiva apropriação criativa de sua seiva, Bultmann assim o faz com a tradição bíblica. Ambos revitalizam suas tradições, o que assinala que destruição fenomenológica e desmitologização teológica são procedimentos positivos ante as calcificações e cristalizações semânticas da filosofia e da teologia. Levando em conta que Bultmann e Heidegger, por meio da desmitologização e da destruição, estão interessados em desvelar o esteio existencial condicionador respectivamente da teologia e da filosofia, pode-se perceber que o primeiro elemento comum entre ambos os pensadores é justamente a existencialidade do ser-aí. Por outro lado, pode-se entender a desmitologização como um procedimento análogo à destruição heideggeriana encerrada, entretanto, no âmbito teológico, o que permite vislumbrar o modo como o pensamento pode - e talvez deva - ser relacionado com saberes ônticos positivamente. Ao mesmo tempo, se levarmos em conta o fato de que a lida heideggeriana, na década de 1920, com textos e contextos teológico-cristãos se identifica quase que inteiramente com a abordagem de Bultmann da bíblia, como se pode vislumbrar em "Introdução à fenomenologia da religião" (Cf. HEIDEGGER, 2010), então, pode-se supor certa interferência da teologia protestante de Marburg em Heidegger. Ainda cabe observar que muitos existenciais de Ser e tempo possuem relação de identidade com grande parte das considerações bultmannianas acerca do kérigma de Jesus (Cf. BULTMANN, 2005). Poder-se-ia supor, então, que a analítica existencial heideggeriana inscreveu diversos elementos teológicos em solo ontológico, o que confirmaria, de certo modo, a afirmação de Bultmann anteriormente reproduzida segundo a qual a análise heideggeriana da existência do ser-aí é uma abordagem "profana" (o que significa dizer "secular") da compreensão bíblica neotestamentária do ser humano. Ainda que aqui não se possa decidir alguma coisa sobre tais questões, deve-se notar a pertinência de se relacionar o pensamento heideggeriano com a teologia do século XX. Talvez, por meio da exploração das relações de Heidegger com o pensamento teoló- 
gico do século XX, sobretudo com as teologias existenciais (Bultmann, Tillich, Rahner), consigamos esclarecer efetivamente que a analítica existencial de Heidegger não nasceu $a b$ ovo. Também ela é uma voz audível da tradição e da renovação de sua história, exatamente como supõe o conceito de ser-aí singular em Ser e tempo. Parece, então, que a singularidade da obra inicial de Heidegger é debitaria de sua relação com a teologia cristã.

\section{Referência Bibliográfica}

ALTMANN, Walter. "Introdução.” In: BULTMANN, Rudolf. Crer e compreender: Ensaios selecionados. São Leopoldo: Sinodal, 2001.

BIBLIA SAGRADA. São Paulo: SBB, 1993.

BIBLIA DE JERUSALEM. São Paulo: Paulus, 2002.

BULTMANN, Rudolf. Crer e compreender: Ensaios selecionados. São Leopoldo: Sinodal, 2001. . Jesus. São Paulo: Teológica, 2005. . Le christianisme primitif dans le cadre des religions antiques. Paris: Petite Bibliotèque Payot, 1969.

CASANOVA, Marco Antônio. Nada a caminho: Impessoalidade, niilismo e técnica na obra de Martin Heidegger. Rio de Janeiro: Forense Universitária, 2006.

\section{Compreender Heidegger. Petrópolis:}

Vozes, 2009.

HEIDEGGER, Martin. Introdução à fenomenologia da religião. In: Fenomenologia da vida religiosa. Petrópolis: Vozes, 2010.
. Sein und Zeit. Tübingen: Max Niemeyer, 2006.

- Ser e tempo. Petrópolis/Bragança

Paulista: Vozes/São Francisco, 2009.

. O conceito de tempo. Trad. Marco Aurélio

Werle. In: Cadernos de tradução. n.2, DF/USP, 1997.

. Marcas do caminho. Petrópolis:Vozes, 2008.

GADAMER, Hans George. Los caminos de Heidegger. Barcelona: Herder, 2002.

RIDDERBOS, Herman. Bultmann. Recife: Mimeo, 1966. 